\title{
EDITORIAL
}

\section{O NURSING NOW DESEMBARCA NO BRASIL PARA EVIDENCIAR A FORÇA E A CAPACIDADE DA ENFERMAGEM}

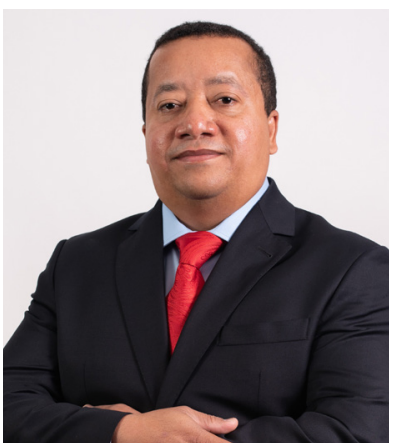

Manoel Neri*

O Programa mundial de fortalecimento da enfermagem - Nursing Now, chega ao Brasil no próximo dia 24 de abril. A campanha global Nursing Now (Enfermagem Agora) destaca o papel da enfermagem e sua importância para o alcance das metas de saúde pactuadas pelos países membros da ONU. A iniciativa foi idealizada pela Organização Mundial da Saúde e pelo Conselho Internacional de Enfermagem (ICN), e está sendo lançada em todos os países que integram o ICN. A ideia é que, durante os próximos dois anos, o ICN e OMS se mobilizem para elevar o status da enfermagem, considerando seu papel central na concepção e implementação das políticas de Saúde que assegurem a universalidade do acesso.

Estudo da OMS prevê que até 2030 irá faltar mais de 9 milhões de enfermeiros no mundo. E faltar profissionais da enfermagem significa desfalcar a área da saúde de forma devastadora. Alguns países, como os da África já passam por essa triste realidade. $O$ Nursing Now tem como meta fortalecer a enfermagem e atrair mulheres e homens para fazerem o curso, se aperfeiçoarem e estarem aptos a se tornarem os profissionais que irão ajudar a cuidar das populações, a realizarem pesquisas, a liderar a implementação de políticas públicas e campanhas contra doenças como tuberculose, Aids, e outras tantas que têm ceifado milhares de vidas em todos os quatro cantos da terra.

O Brasil entrou na campanha por meio de parceria entre - Conselho Federal de Enfermagem (Cofen) e o Centro Colaborador da OPAS/OMS para o Desenvolvimento da Pesquisa em Enfermagem, vinculado à Escola de Enfermagem de Ribeirão Preto da USP (CCOMS-EERP/USP). À intenção é fortalecer nossos profissionais e dar a eles o destaque que merecem na área da saúde, e também disseminar as práticas de enfermagem efetivas e inovadoras, que vem sendo desenvolvidas.

Mas nossa enfermagem grita também por medidas urgentes para que não se esmoreça de vez. Nossos profissionais estão adoecendo pela falta de uma carga horária mais humana, por uma política salarial mais justa, por melhores condições de trabalho, como uma sala de descanso nas instituições. Sim, um lugar para descansar da rotina pesada do dia a dia, porque em muitas instituições onde trabalham, não têm um local com as minimas condições para que possam repor suas energias, após uma jornada de 12 e até 24 horas de trabalho. As políticas de valorização do trabalhador de nosso país, se esqueceram da classe há muitos anos.

Os Conselhos de Enfermagem, a OPAS e a OMS, estão juntos nessa missão de mostrar às autoridades e à população, a urgência de mudar a realidade da categoria. De chamar à razão os parlamentares, governantes, administradores e gestores públicos, para que percebam a necessidade que se faz presente, da aprovação dos projetos de lei que estão no Congresso, parados há mais de 15 anos. Essa percepção precisa chegar também na educação, para que tenhamos cursos de qualidade e possamos formar profissionais qualificados para cuidar da população. Para que sejam barrados os cursos de graduação em EaD, sem estrutura para dar uma boa formação aos estudantes.

Quando falo sobre um melhor atendimento, uma saúde de qualidade, refiro-me a mais de 200 milhões de brasileiras e brasileiros que precisam receber atendimento em muitos momentos de suas vidas. A urgência da enfermagem, dos mais de dois milhões de profissionais espalhados pelo Brasil, é somada à urgência da melhoria da própria saúde do país. Da urgência de fortalecer o SUS, o maior sistema de saúde do mundo, o único universal e irrestrito, e o maior empregador da Enfermagem.

A campanha Nursing Now chega no momento certo, junto com os novos governantes que precisam mudar a realidade da política da saúde para erradicar novamente doenças como o sarampo e a rubéola, que já estavam erradicadas, para dar prosseguimento a programas que visam a saúde e não a doença, a intensificar estudos e pesquisas que vão dar mais qualidade de vida à população.

A meta dos Conselhos de Enfermagem, junto aos organismos de saúde, é fortalecer e valorizar nossos profissionais e mostrar para todos a capacidade de trabalho e a plena condição que eles têm para participarem das discussões sobre as políticas públicas do país. Sua importância é vital, sua força e sua presença em todos os lugares que tem saúde e doença é imprescindivel.

O Nursing Now nasceu para colocar a enfermagem em destaque e na liderança. Aqui no Brasil, queremos mostrar o valor dessa profissão, os trabalhos importantes que são desenvolvidos em todas as áreas em que trabalham. Queremos principalmente, não deixar morrer a profissão que está presente no nascer e que salva vidas. 2020 foi proclamado pela OMS, o Ano da Enfermagem. Queremos que todos os anos sejam de uma enfermagem saudável, respeitada e percebida como uma das áreas mais importantes para a vida. E será em busca dessas metas a atuação do Nursing Now no Brasil.

*Manoel Neri é enfermeiro e presidente do Conselho Federal de Enfermagem. 